\title{
Germany's System of Preventive Detention Considered Through the European Court of Human Rights and the German Federal Constitutional Court
}

\author{
Michael Pösl and Andreas Dürr ${ }^{\star}$
}

\begin{abstract}
The essay is about the recent jurisdiction of the European Court of Human Rights and the German Federal Constitutional Court regarding Germany's system of preventive detention.

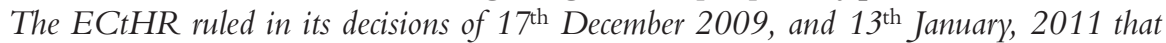
the subsequent prolongation and the subsequent order of preventive detention violate Article 7 $\S 1$ and Article $5 \S 1$ of the ECHR. According to the authors, the only way to cope with these judgements of the ECHR would be the instant release of the detainees from preventive custody. However, the German Federal Constitutional Court concluded in its decision of $4^{\text {th }}$ May, 2011 that the subsequent prolongation or the subsequent order of preventive detention may, at present, only be admissible under the following conditions: (1) there is an extreme threat of the most serious acts of violence or sexual crimes which derive from concrete personal circumstances or an individual's behaviour and (2) the person suffers from a mental disorder. The second condition serves to fulfil the prerequisites of Article $5 \$ 1 \mathrm{ECHR}$, in which only the alternative (e) comes into consideration.

The authors on the one hand compliment the Constitutional Court's methodological approach; on the other hand, they criticize the material content of the judgment. In particular, the ECtHR ruled for Article $5 \S 1$ (e) ECHR (unsound mind), that confinement is only allowed in a hospital or a similar institution. So far, preventive detention is executed in usual prisons. Since the requirement of Article $5 \$ 1$ (e) ECHR is not fulfilled, the German system of preventive detention still violates the ECHR and is against the jurisdiction of the ECtHR. The authors therefore conclude that Germany is still failing to cope with the requirements of the ECtHR and as such, the authority of the High Court is undermined.
\end{abstract}

\section{Introduction}

Preventive detention in German criminal law is a measure regulated by the German Criminal Code which permits the state to keep dangerous criminal offenders in - possibly lifelong - governmental custody beyond actual imprisonment in order to protect the public from them. Similar provisions exist in other states as well. ${ }^{1}$ Yet the measure as such has been the subject of intense discussion, whereby even its constitutionality has been partly called into question. ${ }^{2}$ Considering the criminal law concerning adults alone, the German provisions for preventive

\footnotetext{
* The author Michael Pösl is a research fellow, the author Andreas Dürr is a student assistant at the Chair for German, European and International Criminal Law, Criminal Procedural Law and Commercial Criminal Law of Professor Dr. Helmut Satzger, at the University of Munich.

${ }^{1}$ See for similar instruments in other countries the summary of the Research Services of the German Parliament http://www.bundestag.de/dokumente/analysen/2010/gefaehrliche_straftaeter.pdf [last visited $28^{\text {th }}$ June 2011)].
} 
detention underwent five reforms from 1998 - 2007; it became tightened, extended and thus, in combination with further detailed court rulings, more complex and confusing.

Recent judgments of the European Court of Human Rights and the German Federal Constitutional Court (BVerfG) $)^{3}$ concerning its subsequent prolongation and order have, as such, been drawing particular attention to the measure of preventive detention.

Until 30 $0^{\text {th }}$ January, 1998, preventive detention had to be decreed together with the prison sentence in the final judgment and this had been clearly fixed by law at a maximum term of ten years. Having abolished this maximum term by law, release after ten years was only permitted if there was no further danger of serious crimes against the physical and psychological integrity of potential victims. The abolishment of the maximum term was meant to be explicitly valid for detainees having been sentenced before 30th January, 1998 (subsequent prolongation). ${ }^{4}$

Eventually, in 2004, the subsequent order of preventive detention as such was introduced $^{5}$, which meant that it could be applied to detainees after having served their actual prison sentence even though it had not been decreed or at least reserved in the final judgment before (subsequent order of preventive detention).

By decisions from $17^{\text {th }}$ December, $2009^{6}$ and $13^{\text {th }}$ January, $2011^{7}$, the ECtHR declared that the retroactive abolishment of the maximum term of ten years as well as the subsequent application of preventive detention ${ }^{8}$ violates the European Convention on Human Rights (ECHR). With these judgments in mind, the ECtHR disagreed to the judgment of Germany's Federal Constitutional Court from $5^{\text {th }}$ February, 2004, which neither asserted a violation of the prohibition of retroactive punishment, granted in Article $103 \S 2$ Basic Law ${ }^{9}$, nor ascertained a violation of the detainee's right to liberty, granted in Articles 2 and 104 Basic Law. ${ }^{10}$

After the ECtHR's decisions, the Federal Constitutional Court had to decide in its judgment of $4^{\text {th }}$ May, 2011 ${ }^{11}$, whether the German measure of preventive detention is still constitutional.

The following essay will give a brief explanation about the background ${ }^{12}$ and the impact of the jurisdiction of the ECtHR on domestic law (I.), followed by the

\footnotetext{
2 The constitutionality has been confirmed by the Federal Constitutional Court in BVerfGE 109, p. 133 (151); of a different opinion for instance Hall, Zeitschrift für die gesamte Strafrechtswissenschaft (ZStW) 70 (1958), 41 (53 et seq.); Mayer, Strafrecht AT 1953, p. 36, 39.

${ }^{3}$ In German Bundesverfassungsgericht abbreviated as "BVerfG".

${ }^{4}$ Quarthal, Juristische Ausbildung (JURA) 2011, p. 495.

${ }^{5}$ Gesetz zur Einführung der nachträglichen Sicherungsverwahrung of 23 $3^{\text {rd }}$ July, 2004 (BGBl I p. 1838).

${ }^{6}$ ECtHR, M.v. Germany, Application no. 19359/04, Judgment $17^{\text {th }}$ March, 2009.

${ }^{7}$ ECtHR, Kallweit v. Germany, Application no. 17792/07, Judgment 13 $3^{\text {th }}$ January, 2011; ECtHR, Mautes v. Germany, Application no. 20008/07, Judgment 13 $3^{\text {th }}$ January, 2011; ECtHR, Schummer v. Germany, Application no. 27360/04 and 42225/07, Judgment $13^{\text {th }}$ January, 2011.

${ }^{8}$ ECtHR, Haidn v. Germany, Application no. 6587/04, Judgment $13^{\text {th }}$ January, 2011.

9 The German Constitution is called "Grundgesetz" (engl. Basic Law).

${ }^{10}$ BVerfGE 111, p. 307 et seq.

${ }^{11}$ BVerfG Neue Juristische Wochenschrift (NJW) 2011, 1931 et seq.

${ }^{12}$ See in more detail Pösl, Zeitschrift für das Juristische Studium (ZJS) 2011, 132 et seq.
} 
actual judgment of the Federal Constitutional Court which will be explained (II.) and finally analyzed (III.)

\section{Background}

\section{The measure of preventive detention in contrast to criminal punish- ment}

The German Criminal Code distinguishes between penalties (Strafen) consisting of the main penalties of prison sentences and fines and the side sentence ban on driving, and so-called measures of correction and prevention (Maßregeln der Besserung und Sicherung) to deal with unlawful acts. The ECtHR, as well as German jurisprudence, refer to this phenomenon a "twin-track system of sanctions", 13 . Preventive detention is one of the measures of correction and prevention. Expressed in simplified terms, penalties and measures can be distinguished as follows: While a "penalty" requires the offender's guilt during the commission of the offence in the past, the application of a "measure" requires the prognosis of continuing dangerousness of the former offender and actual detainee in future, this being asserted at the time of decision-making at court. ${ }^{14}$

Contrary to punishment, the purpose of all measures of correction and prevention is protecting the public from a dangerous offender - future offences of the specific offender shall be prevented by influencing him. Thus, the aim and impact of such a measure is preventive - as a negative component, society shall be protected from further criminal offences of the offender, as a positive component the offender shall improve and not commit offences anymore.

Even the measure itself shows the preventive objective of the measures of correction and prevention; as it is written in the German Criminal Code, decisions on the application of such a measure are based on the law in force at the time of the decision, unless the law itself provides otherwise. Thus by a simple act of law, the constitutional prohibition of retroactive penalties is not applicable to measures of correction and prevention; new law can be applied on underlying offences which have been committed before the particular provision coming into force. Due to its preventive nature, a measure has to be justified constantly ${ }^{15}$; the thought of retaliation does not play any role when applying such a measure. However, differing from measure to measure, the negative and the positive components of prevention enjoy different grades of importance.

Preventive detention requires the offender's guilt at the time of the offence; while guilt, therefore, is a necessity, it is not a sufficient condition for the application of preventive detention. ${ }^{16}$ Apart from the guilty commission of the offence, preventive detention requires the continuing dangerousness of the offender; the guilty commis-

\footnotetext{
${ }^{13}$ ECtHR, M. v. Germany (fn. 6), margin no. 45; Wessels/Beulke, Strafrecht AT, 40 th ed. 2010, margin no. 11.

${ }^{14}$ Roxin, Strafrecht AT I, 41 st ed. 2006, § 1 margin no. 3.

${ }^{15}$ Grosse-Brömer/Klein, Zeitschrift für Rechtspolitik (ZRP) 2010, p. 172.

${ }^{16}$ BVerfG NJW 2004, p. 739 (746).
} 
sion is only the inducement for the examination of the dangerousness. Therefore, the target group of preventive detention, in a legal sense, are responsible but incorrigible persons. ${ }^{17}$ As long as this dangerousness continues, preventive detention must not be ended. Even though according to the law, the purpose of preventive detention consists both in the protection of the public from the still dangerous offender on the one hand, and the reintegration of the offender into society on the other, in the case of preventive detention, the protection of society from the offender and thus the negative component of prevention is clearly in the foreground. ${ }^{18}$ Thus one may say that preventive detention is the "most powerful weapon" 19 in German criminal law: even after having served the prison sentence, the offender must remain in custody, only because of the continuity of his dangerousness.

As already hinted at in the text above, there are three different types of preventive detention. Introduced in 1933, the so-called primary preventive detention is already decreed in the judgment together with the sentence. The court investigates the dangerousness of the offender for the public at the time of the pronouncement of the judgment and decrees preventive detention for the offender for the time after the prison sentence has been served. Out of more than 500 detainees, 95\% are under primary preventive detention.

If the court cannot definitely ascertain at the time of the pronouncement of the judgment whether the offender will still remain a danger to the public after serving the prison sentence, the court can reserve the application of preventive detention for a later date than the judgment itself (reserved preventive detention). Such a reservation was only used in 37 cases until June 2010 and, in any event, it does not ultimately mean that the preventive detention will be applied automatically.

As a result of legislators' recent reformatory efforts ${ }^{20}$, subsequent preventive detention - a process whereby a court, not having been involved in the original judgment and without any reservation in the original judgment, takes a decision regarding the application of preventive detention after the offender has served the sentence - will soon, for the main part, be a thing of the past. Since its introduction, it has been applied in around a dozen cases. ${ }^{21}$

\section{The prohibition of retroactive punishment}

In general, the Basic Law permits an unfavourable law only if the legal consequences and effects do not enter into force before the promulgation of the law. If the temporal application of a law is determined on a date which lies before its legal existence, before it is "legally valid", the law is retroactive. ${ }^{22}$ Thus, the prohibition

\footnotetext{
${ }^{17}$ Ostendorf/Bochmann, ZRP 2007, p. 146.

${ }^{18}$ Roxin (fn. 14), § 3 margin no. 64.

${ }^{19}$ Kreuzer, Zeitschrift für Internationale Strafrechtsdogmatik (ZIS) 2006, p. 145 (151).

${ }^{20}$ see BT-Drs. 17/3403, p. 2.

${ }^{21}$ http://www.liberale.de/files/5781/Sicherungsverwahrung_FragenAntworten.pdf date: $9^{\text {th }}$ August, 2010 [last visited $28^{\text {th }}$ June, 2011].

22 BVerfGE 63, p. 343 (353).
} 
of retroactive punishment in Article $103 \S 2$ Basic Law and Article 7 \$ 1 ECHR prohibits the application of a legal provision which has not been in force at the time of the commission of the offence and, accordingly, protects someone from being punished more severely than was prescribed by law at the time of the commission of the offence. In criminal law, the prohibition of retroactive punishment must not be the subject of consideration ${ }^{23}$, it is an absolute prohibition.

In principle, this is a national and international consensus. ${ }^{24}$ In each and every legal system, the prohibition of retroactive punishment is based on the same idea nulla poena sine lege - no penalty without law ${ }^{25}$. However, due to the different development of this principle in particular domestic legal systems, a number of differences have arisen, as a comparison between Article $103 \S 2$ Basic Law and Article $7 \S 1$ ECHR shows. Since Article $7 \S 1$ ECHR cites "international law" as a valid legal foundation for a penalty, even customary international law can be used as a valid ground for the criminal liability and punishment of a member state's citizen. $^{26}$ The only essential criterion is the offender having been able to predict the punishment of his behaviour, even if he needs the court's assistance. ${ }^{27}$ The margin of Article $103 \S 2$ Basic Law is different; punishment may only be based on a legal statute, whereas Article $104 \S 1$ Basic Law even explicitly requires a formal act of parliament. $^{28}$

Further differences may occur due to different interpretations of the term "penalty". The definition of the word "penalty" is decisive for the reach and applicability of this principle. Only when a "penalty" is imposed on the offender does a violation of the prohibition of retroactive punishment become an issue.

\section{The judgment of the Federal Constitutional Court of 5th February, 2004}

On $5^{\text {th }}$ February, 2004, the Federal Constitutional Court decided on the constitutional complaint of a detainee upon whom preventive detention had been imposed before 1998 for the first time and which had been ordered to be continued due to continuing dangerousness under the provisions of the new legislation. Thus the case was about the subsequent prolongation of primary preventive detention. The decisive factor for determining whether there has been a violation of the

\footnotetext{
${ }^{23}$ Pieroth/Schlink, Staatsrecht II, 27 th ed. 2008, margin no. 1201.

${ }^{24}$ Cf. Satzger, in: Satzger/Schmitt/Widmaier, Kommentar zum StGB, 2009, § 1, margin no. 49; Frowein/Peukert, Kommentar zur EMRK, $3^{\text {rd }}$ ed. 2009, Article 7, margin no. 2, 7; Gollwitzer, in: Karlsruher Kommentar zur StPO, $6^{\text {th }}$ ed. 2008, Article $15 \mathrm{IPbpR}$, margin no. 6; due to Article $52 \S 3$ of the Charter of Fundamental Rights of the European Union this interpretation applies to its Article 49.

${ }^{25}$ Cf. A. von Feuerbach, Lehrbuch des gemeinen in Deutschland geltenden peinlichen Rechts, $1^{\text {st }}$ ed. 1801 , p. 20 ; for the legal history see more detailed Schreiber, Gesetz und Richter - Studien zur geschichtlichen Entwicklung des Satzes ,nulla poena sine lege“", 1976; more general about the principle of legality Bott/Krell, ZJS 2010, p. 694 (695 et seq.).

${ }^{26}$ Gollwitzer, in: Löwe-Rosenberg, Kommentar zur StPO, 26 ${ }^{\text {th }}$ ed. 2006-2010, vol. 11 EMRK/IPbpR, margin no. 10.

${ }^{27}$ Satzger, Internationales und Europäisches Strafrecht, $5^{\text {th }}$ ed. 2011, 11 , margin no. 86.

${ }^{28}$ Kadelbach, in: Grote/Marauhn, EMRK/GG Konkordanzkommentar, 2006, chapter 15, margin no. 7, 8 with further examples.
} 
prohibition of punishment under Article $103 \S 2$ Basic Law is the ascertainment of preventive detention as a "penalty" within the meaning of the statute. In the view of the Federal Constitutional Court, the following prerequisites have to be fulfilled in order to subsume a measure under the item "penalty" in Article $103 \S 2$ Basic Law $^{29}$ :

(1) The measure in question must be a governmental one.

(2) The measure is a condemnation of unlawful, culpable behaviour.

(3) The measure imposes a sanction that serves the compensation of guilt.

Thus "penalty" is first of all an expression of retaliating justice and a reaction to unlawful behaviour. The basic concept and prerequisite for the imposition of a penalty is the principle of guilt.

This principle does not correspond to the measure of preventive detention. The purpose of preventive detention is the individual prevention in the form of the detention of an offender who is continuously dangerous in combination with offers of therapy. Irrespective of whether the personal guilt and responsibility of the offender justifies such a measure, the preventive detention is bound only to the future dangerousness of the offender.

The aim of this measure is the future protection of the public from the offender. ${ }^{30}$ Since the preventive detention is not a reaction of the state to any legal wrongs committed, but rather a precautionary measure affecting the future, the character of preventive detention is purely preventive, and not in any way penal. Its imposition is not a reaction to the guilt realized by the underlying offence, but a reaction to the dangerousness of the offender which is shown in the underlying offence.

According to the Federal Constitutional Court, not even the overlaps in the aims of imprisonment and preventive detention ${ }^{31}$ are sufficient to justify subsuming preventive detention under the term "penalty", since these overlaps occur solely on the level of prevention. ${ }^{32}$

Since the Federal Constitutional Court does not assert preventive detention as a penalty and therefore denies the application of Article $103 \S 2$ Basic Law when decreeing it, the subsequent prolongation of that detention is not a violation of the prohibition of retroactive punishment for the purposes of Article $103 \S 2$ Basic Law.

Even an infringement of the detainee's trust in his release (Vertrauensschutzgebot) protected by the Articles $2 \S 2$ and $20 \S 3$ of the Basic Law could not be found by the Federal Constitutional Court. ${ }^{33}$

${ }^{29}$ Cf. BVerfG NJW 2004, p. 739 (744).

${ }^{30}$ BVerfG NJW 2004, p. 739 (746).

${ }^{31}$ See under II. 4. a) bb).

32 BVerfG NJW 2004, p. 739 (747).

${ }^{33}$ BVerfG NJW 2004, p. 739 (748 et seq.). 
4. The ascertainment of the subsequent prolongation of preventive detention by the ECtHR in its decision of 17th December, 2009 19359/04 and its decision of 13th January, 2011 - 17792/07, 20008/07, 6587/04, 27360/04 \& 42225/07

The constellation in the decision " $M$ " from 17th December, 2009 was parallel to the facts in the decisions "Kallweit", "Mautes" and "Schummer", 34 , decided on $13^{\text {th }}$ January, 2011. Before 1998, yearlong prison sentences and afterwards preventive detention were imposed on each applicant. At the time of the judgment, the maximum term of preventive detention was ten years, until the time limit was abolished by law in 1998. After 10 years having passed, the courts having received competence only by a change in law prolonged the detention. The applicants appealed against these decisions and, finally, even filed constitutional complaints which were not successful. ${ }^{35}$

\section{a) Violation of the prohibition of retroactive punishment, Article $7 \S 1$ S. 2 ECHR}

According to the jurisdiction of the ECtHR, Article 7 is violated if someone is sentenced to a penalty though the offence was not punishable according to the law valid at the time of the offence. The prohibition of retroactive laws and penalties is violated if the temporal span of application gets extended on actions which occurred before the law came into force. ${ }^{36}$ Thus, it is decisive for the applicability of Article 7 $\S 1$ ECHR and for the applicability of the prohibition of retroactive laws and penalties if the preventive detention can be ascertained as a "penalty" in this sense.

As the ECtHR interprets the ECHR autonomously, there is also an autonomous definition of the item "penalty" in Article $7 \S 1 \mathrm{ECHR}^{37}$, which is completely different to the one of the German Federal Constitutional Court. The offender's guilt does not play a role for the ECtHR. In order to assert if a measure can be qualified as a "penalty" in sense of Article 7 ECHR, the ECtHR applies the "Welch"-criteria, named after the first case for which the ECtHR used this standard: ${ }^{38}$

(1) The measure in question is imposed following conviction for a "criminal offence".

(2) The measure in question has the nature and purpose of a penalty, for example a prison sentence.

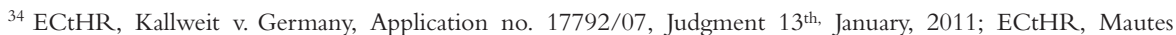
v. Germany, Application no. 20008/07, Judgment 13 ${ }^{\text {th }}$ January, 2011; ECtHR, Schummer v. Germany, Application no. $27360 / 04$ and $42225 / 07$, Judgment $13^{\text {th, January } 2011 .}$

${ }_{35}$ M's complaint amounted in the judgment of the Federal Constitutional Court described above.

${ }^{36}$ Kadelbach (fn. 28), margin no. 10, 28.

${ }^{37}$ Article 7 § 1 ECHR: "No one shall be held guilty of any criminal offence on account of any act or omission which did not constitute a criminal offence under national or international law at the time when it was committed. Nor shall a heavier penalty be imposed than the one that was applicable at the time the criminal offence was committed".

${ }^{38}$ Established law practice since ECtHR, Welch v. United Kingdom, Application no. 17440/90, Judgment $9^{\text {th }}$ February, 1995, margin no. 28.
} 
(3) The domestic law characterises the measure in question as a penalty. ${ }^{39}$

(4) The measure in question gets made and implemented after or in context with a criminal procedure.

(5) Finally, the ECtHR takes the severity of the measure in question into account, whereas the severity alone must not be decisive, since even many non-penal measures can have a substantial impact on the person concerned.

\section{aa) Imposition after a criminal conviction}

The ECtHR notes that preventive detention can be imposed only against someone who was given a prison sentence of at least two years according to the law. Thus, the measure gets imposed after a conviction; the first criterion is therefore fulfilled. ${ }^{40}$

\section{bb) Nature and purpose of the measure}

The ECtHR then makes a really huge effort to investigate the nature and purpose of preventive detention in German law. The ECtHR compares the legal and practical aspects of both preventive detention and imprisonment, and concludes that both kinds of sanction are so similar that "nature and purpose" also indicate that preventive detention constitutes a "penalty" within the meaning of Article $7 \S 1$ ECHR.

The practical execution of both preventive detention and imprisonment in Germany can barely be distinguished from one another. Though in separate wings, persons subject to preventive detention are still detained in ordinary prisons. Slight differences compared to the detention conditions of an ordinary prisoner serving his sentence, including privileges such as detainees' right to wear their own clothes and to further equip their more comfortable prison cells, cannot hide the fact that there is no substantial difference between the serving of a prison sentence and that of a preventive detention order. ${ }^{41}$ In the end, both prisoners and detainees are enclosed by the same thick walls.

Furthermore, the actual treatment of the detainees is not as consistent with the strictly preventive purposes of the preventive detention, as the Federal Constitutional Court had supposed it to be. Both the ECtHR and the Council of Europe's Commissioner for Human Rights agree that persons subject to preventive detention, in view of its potentially indefinite duration, are in particular need of psychological care and support in order to obtain a realistic chance of being released from detention. $^{42}$

Moreover, the German Execution of Sentences Act shows that there is no strict border between prison sentence and preventive detention. There are very few

\footnotetext{
39 Therefore contrary to Müller, Strafverteidiger (StV) 2010, p. 207 (208) the measure's characterisation by national law plays a role.

${ }^{40}$ ECtHR, M. v. Germany (fn. 6), margin no. 124.

${ }^{41}$ ECtHR, M. v. Germany (fn. 6), margin no. 127.

${ }^{42}$ ECtHR, M. v. Germany (fn. 6), margin no. 129.
} 
provisions dealing specifically with the execution of preventive detention; apart from these, the provisions on the execution of prison sentences apply. ${ }^{43}$

Finally, there are overlaps between the aims of criminal sentencing and preventive detention. According to Articles 2 and 129 of the Execution of Sentences Act, the execution of both penalties and measures of correction and prevention serves two aims, namely to protect the public and to help the detainee to become capable of leading a socially responsible life outside prison. Even though it could be said that penalties mainly serve punitive purposes whereas measures of correction and prevention are mainly aimed at prevention, it is nonetheless clear that the aims of these sanctions partly overlap. Furthermore, given its unlimited duration, preventive detention may well be understood as an additional punishment for an offence by the persons concerned and entails a clear deterrent element. ${ }^{44}$ The validity of this point gets underlined by the common practice of the German criminal courts, which are used to threatening preventive detention before imposing it. ${ }^{45}$

In the end, the ECtHR concludes that the aim of prevention does not get excluded by another punitive purpose and might sometimes even be the constitutive element of a penalty. ${ }^{46}$

\section{cc) Nature of the proceedings}

Regarding the procedures involved in the making and implementation of orders for preventive detention, the Court observes that preventive detention is decreed by the (criminal) sentencing courts. Its execution is determined by the courts competent for the enforcement of punishment, that is, courts also belonging to the criminal justice system, in a separate procedure. $^{47}$

\section{dd) Severity of the measurement}

Even the severity of the measure indicates the penal character of preventive detention within the meaning of Article $7 \S 1$ ECtHR. The detainee is only released if he is no longer dangerous to the public anymore. Regarding the complete lack of specific therapies, this will hardly ever be the case. Thus preventive detention can mean lifelong detention. ${ }^{48}$

\section{ee) Result}

The ECtHR therefore considers preventive detention as it is practiced in Germany to be a penalty within the meaning of Article 7 ECHR. Thus, the order of

\footnotetext{
${ }^{43}$ ECtHR, M. v. Germany (fn. 6), margin no. 127.

${ }^{44}$ ECtHR, M. v. Germany (fn. 6), margin no. 130.

${ }^{45}$ Kinzig, Neue Zeitschrift für Strafrecht (NStZ) 2010, p. 233 (237) with further references.

${ }^{46}$ ECtHR, M. v. Germany (fn. 6), margin no. 130 with reference to ECtHR, Welch v. United Kingdom (fn. 38), margin no. 30 .

${ }^{47}$ ECtHR, M. v. Germany (fn. 6), margin no. 131.

${ }^{48}$ ECtHR, M. v. Germany (fn. 6), margin no. 129.
} 
prolongation in excess of the former maximum term of ten years constitutes a violation of the prohibition of retroactive punishment. ${ }^{49}$

\section{b) Violation of the right to liberty and security, Article $5 \S 1 \mathrm{ECHR}$}

\section{aa) Justification according to Article 5 \$ (a) ECHR}

In the view of the ECtHR, both the original order for the preventive detention and the decision of the domestic court to prolong the preventive detention did not comply with the requirements of Article $5 \S 1$ (a) ECHR. Article $5 \S 1$ (a) ECHR permits the deprivation of liberty, including preventive detention, only after a conviction by a competent court. This "conviction" has to contain both the finding of guilt after it has been established in accordance with the law that there has been an offence and the imposition of a penalty or other measure involving deprivation of liberty. ${ }^{50}$ Moreover, the word "after" in Article $5 \S 1$ (a) ECHR indicates that there must be a sufficiently causal connection between the conviction and the deprivation of liberty. ${ }^{51}$

In the ECtHR's view, this causal connection between the conviction some time before 1998 and the order of prolongation of the preventive detention in the year 2001, was not given. With the passage of time, the link between the initial conviction and a further deprivation of liberty gradually becomes less strong. ${ }^{52}$

In addition, the competence of the domestic court which made a decision regarding the prolongation was only derived from the change in the law in $1998 .{ }^{53}$ This swing of competence from the court, in particular, which ordered the preventive detention in the underlying judgment to another court which did not elaborate the guilt of the detainee caused by a change in the law, was the ECtHR's main concern. 54

\section{bb) Justification according to Article 5 § (c) ECHR}

The ECtHR denies a justification of the deprivation of liberty via Article $5 \S 1$ (c) ECHR. Due to the lack of determinability of a potential victim as well as place and time of commission, there is no necessity "to prevent his committing an offence“. 55

\section{cc) Justification according to Article $5 \$ 1$ (e) ECHR}

Finally, the ECtHR considers whether a justification according to Article $5 \S 1$ (e) ECHR is appropriate. Article $5 \S 1$ (e) ECHR requires ${ }^{56}$ the reliable evidence of the detainee being "of unsound mind" which has to be proven by medical

\footnotetext{
${ }^{49}$ ECtHR, M. v. Germany (fn. 6), margin no. 123; ECtHR, Kallweit. v. Germany (fn. 7), margin no. 66-69.

${ }^{50}$ ECtHR, M.v. Germany (fn. 6), margin no. 95.

${ }^{51}$ ECtHR, M. v. Germany (fn. 6), margin no. 96.

${ }^{52}$ ECtHR, Weeks v. United Kingdom, Application no. 9787/82, Judgment 2nd March, 1987, margin no. 42.

${ }^{53}$ ECtHR, M.v. Germany (fn. 6), margin no. 100.

${ }^{54}$ ECtHR, M. v. Germany (fn. 6), margin no. 101.

${ }^{55}$ ECtHR, M. v. Germany (fn. 6), margin no. 102; ECtHR, Haidn v. Germany (fn. 8), margin no. 90.
} 
expertise establishing "a true mental disorder" in front of the competent author${ }^{i t y}{ }^{57}$; this true mental disorder must be serious enough to justify his deprivation of liberty by compulsory hospitalisation; the validity of continued confinement depends upon the persistence of such a disorder. Furthermore, there must be some relationship between the ground of permitted deprivation of liberty relied on and the place and conditions of detention. In principle, the "detention" of a person as a mental health patient will only be "lawful" for the purposes of Article $5 \S 1$ (e) ECHR if it is performed in a hospital, clinic or other appropriate institution. ${ }^{58}$ In these cases, according to the ECtHR, the establishment of a true mental disorder failed to be proven, which was further underlined by the fact that preventive detention was executed in prisons.

\section{ECtHR "Haidn"- subsequent preventive detention}

The fourth decision of the ECtHR from 13 ${ }^{\text {th }}$ January, 2011 not concern primary preventive detention but subsequent preventive detention - the type of preventive detention which is decreed after the prison sentence has been served without having already been imposed with the underlying conviction.

\section{a) Violation of Article $5 \$ 1$ ECHR}

Subsequent preventive detention violates the right to liberty and security, Article $5 \S 1$ ECHR. ${ }^{59}$ The ECtHR denied a justification according to Article $5 \S 1$ (a) ECHR. Since there was no preventive detention decreed in the underlying conviction but decreed later by the domestic court which gained competence only because of a change in the law, the ECtHR does not see a sufficient causal connection between the underlying conviction and the deprivation of liberty. ${ }^{60}$

\section{b) Violation of Article 7 ECHR}

Though the ECtHR did not investigate the compatibility of preventive detention with Article $7 \S 1 \mathrm{ECHR}^{61}$, the assessment of preventive detention as a "penalty" made in the previous decisions - indicates a violation of Article $7 \mathrm{ECHR} .{ }^{62}$

\footnotetext{
${ }^{56}$ For the so-called Winterwerp-criteria cf. ECtHR, Winterwerp v. The Netherlands, Application no. 6301/73, Judgment $24^{\text {th }}$ October, 1979 , margin no. 39.

57 This means in a hospital, a clinic or another appropriate institution.

${ }^{58}$ Established law practice since ECtHR, Ashingdane v. United Kingdom, Application no. 8225/78, Judgment $28^{\text {th }}$ May, 1985, margin no. 44; ECtHR, Kallweit v. Germany (fn. 7), margin no. 46, 55, 57.

${ }^{59}$ ECtHR, Haidn v. Germany (fn. 8), margin no. 97.

${ }^{60}$ ECtHR, Haidn v. Germany (fn. 8), margin no. 88.

${ }^{61}$ The applicant did not claim a violation of Article 7 ECHR.

${ }^{62}$ Federal Supreme Court (BGH) NStZ 2010, p. 567 (568); Kinzig, NStZ 2010, p. 233 (239); Müller, Europarecht (EuR) 2011, p. 418 (428 et seq.).
} 


\section{The impact of the jurisdiction of the ECtHR on German domestic law}

First of all, in order to avoid misunderstandings, one has to state the following: The ECtHR does not declare preventive detention in total being incompatible with the ECHR; in general, a preventive deprivation of liberty (preventive detention) is compatible with the guarantees of the ECHR. ${ }^{63}$ Only those cases and detainees affected by the judgments considered above, whose conviction occurred before the abolishment of the maximum term of preventive detention in 1998 or before the introduction of the subsequent preventive detention in 2004, are relevant.

In order to understand the impact of the jurisdiction of the ECtHR on these cases, the relevance of the ECHR and the jurisdiction of the ECtHR in relation to the German legal system has to be explained.

\section{a) The impact of the ECHR on domestic law}

The ECHR is an international treaty in the sense of Article 1 in conjunction with Article 2 (a) VCLT. ${ }^{64}$ Article 1 ECHR imposes the duty on the signature states to secure the rights and freedoms of the convention to everyone under their jurisdiction. ${ }^{65}$ The aim of the ECHR is to grant a minimum standard of protection of Human Rights in the signature states. The ECHR was ratified in Germany by an act from $7^{\text {th }}$ August, 1952. ${ }^{66}$ In general, according to Article 59 \& 2 Basic Law, international treaties have the rank of a simple statutory act after their transformation into domestic law via a transformative act. ${ }^{67}$ However, pursuant to the jurisdiction of the Federal Constitutional Court, the principle lex posterior derogat legi priori ${ }^{68}$ is not valid in the case of the ECHR; due to the principle of interpretation in conformity with International Law, all German law shall be interpreted in the light of the ECHR. ${ }^{69}$ Even the German Basic Law shall be interpreted in accordance with the ECHR, unless the interpretation has a negative impact on the protection standard of the Basic Law, a consequence which also has to be avoided due to the role of the ECHR itself anyway. ${ }^{70}$ Notwithstanding, the ECHR is ranked under the Basic Law in the legal hierarchy. ${ }^{71}$

A violation of the principle of interpretation in conformity with International Law by a court means a violation of the rule-of-law-principle and in conjunction

\footnotetext{
${ }^{63}$ ECtHR, M.v. Germany (fn. 6), margin no. 93 in respect of Article $5 \S 1$ (a) ECHR; last ECtHR, Grosskopf v. Germany, Application no. 24478/09, Judgment. 21 $1^{\text {st }}$ October, 2010, margin no. 45-54.

${ }^{64}$ Vienna Convention on the Law of Treaties, http://untreaty.un.org/ilc/texts/instruments/english/conventions/ 1_1_1969.pdf [last visited 28 ${ }^{\text {th }}$ June, 2011].

${ }^{65}$ Hoffmann/Mellech/Rudolphi, JURA 2009 , p. 256 (257).

${ }^{66}$ Gesetz über die Konvention zum Schutze der Menschenrechte und Grundfreiheiten of $7^{\text {th }}$ August, 1952, BGB1 II S, 685 .

${ }^{67}$ Schweitzer, Staatsrecht III, $10^{\text {th }}$ ed. 2010, margin no. 447.

68 "The later act prevails against the earlier act"

${ }^{69}$ Satzger (fn. 27), § 11, margin no. 13.

${ }^{70}$ BVerfGE 111, p. 311 (317).

${ }^{71}$ Other opinions in favour of constitutional rank or at least of a rank between the constitution and the statutory law were not successful because of various objections; cf. Quarthal, JURA 2011, p. 495 (496 et seq.).
} 
with a violation of a fundamental right, a constitutional complaint at the Federal Constitutional Court is admissible. ${ }^{72}$

\section{b) The meaning and relevance of the jurisdiction of the ECtHR - international perspective}

\section{aa) The ECtHR's interpretation of the ECHR}

As described already above, the ECtHR interprets the ECHR autonomously; the Court creates its own terms and definitions in order to prevent the member states from diminishing the protection standard of the ECHR by creating their own terms and definitions. ${ }^{73}$ In comparison to the interpretation of German law by the domestic courts, the genesis of the ECHR only plays a subordinate role in the interpretation of the ECHR by the ECtHR.

One reason for this rule of interpretation is Article $31 \S 1$ VCLT, which states that the methods of interpreting international treaties are the terms of the treaty in their context and in the light of its object and purpose. The genesis of the treaty in form of the preparatory work and the circumstances of its conclusion are only meant to be a supplementary means of interpretation, Article 32 VCLT. Another reason is the fact that the ECtHR interprets the Convention as a "living instrument which must be interpreted in the light of present-day conditions" "74 in matters of economical, social and ethical circumstances. ${ }^{75}$

\section{bb) The decisions of the ECtHR: impact inter partes and precedence effect for parallel cases}

In the event of a conviction by the ECtHR, the member states have to pursue the judgment according to Article $46 \S 1$ ECHR. The judgments are not set aside (Article 44 ECHR deems judgments to be of declaratory nature), they just admonish the violation of the convention and do not give subjective protection. ${ }^{76}$

Basically, the judgments have only impact inter partes after becoming final, i. e. only the parties from the process are bound to the judgment. From a negative point of view, a conviction means that the particular state must not denote its behaviour according to the Convention anymore ${ }^{77}$; from a positive point of view, a judgment which finds an infringement imposes the legal obligation on the member state to put an end to the breach and make reparation as a consequence in such a way as to restore as far as possible the situation existing before the breach ${ }^{78}$. The way the state complies with this obligation is subject to its own discretion. ${ }^{79}$ Only in exceptional

\footnotetext{
72 BVerfGE 111, p. 311 (316).

${ }^{73}$ See above II. 4. a).

${ }^{74}$ See among others: ECtHR, Tyrer v. the United Kingdom, Application no. 5856/72, Judgment 25 ${ }^{\text {th }}$ April, 1978, margin no. 31.

${ }^{75}$ Mayer-Ladewig, Kommentar zur EMRK, $2^{\text {nd }}$ ed. 2006, Einleitung, margin no. 32.

76 Satzger, JURA 2009, p. 758 (760); although the ECtHR may afford a just satisfaction to the injured party if the internal law of the High Contracting Party allows only partial reparation to be made (Article 41 ECHR)

${ }^{77}$ Frowein/Peukert (fn. 24), Article 53, margin no. 2.

${ }^{78}$ ECtHR, Maestri v.Italy, Application no. 39748/98, Judgment 17th February, 2004, margin no. 47.
} 
cases does the ECtHR describe the measure to be taken in order to satisfy the obligation deriving from Article $46 \S 1$ ECHR, in particular when the specific violation of the convention does not leave any choice regarding the possible measures. ${ }^{80}$ Apart from the obligation to end the particular violation, the judgment also imposes the duty not to repeat the violation; in this context, the state has to take measures in order to avoid future violations. ${ }^{81}$

Though the decisions of the ECtHR do not obtain any impact erga omnes, they resemble the actual state of the Convention as a "living instrument", since according to Article 19 ECHR, the ECtHR is obliged to ensure compliance with the Convention and is therefore entitled and obliged to its interpretation. Since the entire member states committed themselves to grant the rights described in the Convention, Article $1 \mathrm{ECHR}$, the judgments of the ECtHR have a precedential effect even for states which did not take part in the actual process. ${ }^{82}$

\section{c) The impact of the ECtHR's jurisdiction in German law - "Görgülü'"}

Due to the formal status of the ECHR as a simple statutory act, the ECtHR since it is an organ of the Convention itself (see Article 19 ECHR) ${ }^{83}$ - does not obtain a higher rank than the domestic courts.

\section{aa) Material impact}

In the end, the Federal Constitutional Court conceded the special relevance to the decisions of the ECtHR which they deserve due to resembling the actual state of development of the ECHR. The Convention has to be taken into account and to be applied within the limits of a methodically passable interpretation of the domestic law. ${ }^{84}$ The Federal Constitutional Court stated that a decision of the ECtHR binds all governmental organs and imposes the obligation on them to end a persistent violation of the convention and to restore status according to the convention within their competence, without violating the rule-of-law principle (Article $20 \S 3$ Basic Law) in conjunction with the particularly applicable fundamental right. In this context, a violation of Article $20 \S 3$ Basic Law is already the case if a decision of the ECtHR is not taken into account within a pure, methodically passable interpretation of the domestic law; only if the fundamental basics of the Basic Law might be violated are the governmental organs entitled not to consider the decisions of the ECtHR. However, in such a case the particular organ has to explicitly explain the reasons why it does not follow the jurisdiction of the ECtHR. ${ }^{85}$

\footnotetext{
${ }^{79}$ Hoffmann/Mellech/Rudolphi, JURA 2009, p. 256 (257); Quarthal, JURA 2011, p. 495 (496).

${ }^{80}$ ECtHR, Kallweit. v. Germany (fn. 7), margin no. 81.

${ }^{81}$ Grabenwarter, Juristenzeitung (JZ) 2010, p. 857 (860).

82 Grabenwarter, JZ 2010, p. 857 (861); Quarthal, JURA 2011, p. 495 (498).

${ }^{83}$ Article 19 ECHR: "To ensure the observance of the engagements undertaken by the High Contracting Parties in the Convention and the Protocols thereto, there shall be set up a European Court of Human Rights, hereinafter referred to as "the Court". It shall function on a permanent basis."

${ }^{84}$ BVerfGE 111, p. 307 (317).
} 
Then again, the formal status of the ECHR as a simple statutory act in German law has the effect that the obligation of German courts to an interpretation of the domestic law according to the convention is restricted to the margins of interpretation which are available anyway; even a "schematic execution" of the jurisdiction of the ECtHR, which infringes superior law, might violate fundamental rights in conjunction with the rule-of-law principle. ${ }^{86}$ This may occur especially in constellations with several subjects of fundamental rights, as is the case in private law especially. 87

Finally, the Federal Constitutional Court seeks to bring about the adoption of the jurisdiction of the ECtHR into the well-elaborated domestic legal system as gently as possible. ${ }^{88}$ In particular, the Federal Constitutional Court refuses to incorporate, the international law definitions of the ECtHR into its jurisdiction regarding the Basic Law without considerable reflection; if an autonomously created definition of the ECtHR differs from the definition made by the Federal Constitutional Court, for example, then the Federal Constitutional Court takes the jurisdiction of the ECtHR into account only within its own assessment of proportionality. ${ }^{89}$

\section{bb) Procedural impact}

In procedural respects, a decision of the ECtHR can establish a reason for the reopening of a case under Article 359 no. 6 German Criminal Procedure Code (StPO) ${ }^{90}$ However, the judgment must involve the violation of the convention asserted by the ECtHR. ${ }^{91}$

Regarding the jurisdiction of the Federal Constitutional Court, a decision of the ECtHR which differs from the jurisdiction of the Federal Constitutional Court regarding a specific constellation - though a clearly written law as in the German Criminal Procedure Code does not exist - leads to a suppression of the finality of the decisions of the Federal Constitutional Court. If, after the judgment, changes in the factual and/or legal circumstances occur, opposing legal force does not apply. ${ }^{92}$ Due to the principle of interpreting even the Basic Law consistently with international law ${ }^{93}$, the Federal Constitutional Court tries to make use of existing margins of interpretation in order to avoid violations of the Convention. Thus, the decisions of the ECtHR are equal to a change of the legal situation. ${ }^{94}$

\footnotetext{
${ }^{85}$ BVerfGE 111, p. 307 (323).

${ }^{86}$ BVerfGE 111, p. 307 (329).

${ }^{87}$ BVerfGE 111, p. 307 (331).

${ }^{88}$ BVerfGE 111, p. 307 (327).

${ }^{89}$ Pioneering BVerfGE 111, p. 307 (324), last confirmed by BVerfG NJW 2011, p. 1931 (1936).

${ }^{90}$ Other Court Procedure Acts contain similar provisions, e. g. Article 580 no. $8 \mathrm{ZPO}$ and referring to the latter Article 153 VwGO, Article 79 ArbGG, Article 179 SGG and Article 134 FGO.

${ }^{91}$ Schmidt, in: Karlsruher Kommentar zur StPO, $6^{\text {th }}$ ed. 2008, § 359, margin no. 40. (84).

${ }^{92}$ Established law practice, cf. BVerfGE 33, p. 109 (203 et seq.); BVerfGE 87, p. 341 (346); BVerfGE 109, p. 64

${ }^{93}$ See also the "Görgülü" decision BVerfGE 111, p. 307 et seq.

${ }^{94}$ BVerfG NJW 2011, p. 1931 (1934).
} 


\section{The Federal Constitutional Court's judgment of 4th May, $2011^{95}$}

Both the legislator and the Federal Constitutional Court try, on the one hand, to comply with the ECtHR's requirements, and on the other hand, to protect the public from highly dangerous criminal offenders.

In terms of the legislator's reforms ${ }^{96}$, the new Therapy Confinement Act $(\text { ThUG })^{97}$ has to be pointed out. According to Article 1 of this Act, a person might be confined in a suitable institution with corresponding therapy if his preventive detention has to cease due to the prohibition of retroactive aggravation of punishment - this means because of the ECtHR's evaluation of Article 5 and 7 of the Convention. The Civil Chamber of the Regional Court (Landgericht) would have jurisdiction over that (Article $4 \S 1$ ThUG).

In reaction to the ECtHR's decisions, some persons affected by the subsequent prolongation or the subsequent order of preventive detention, respectively turned to the courts competent for the enforcement of punishment, demanding immediate release. As a result, the courts drew different conclusions from the ECtHR's decisions - even the Criminal Senates of the Federal Supreme Court $(\mathrm{BGH})^{98}$ disagreed: Some courts ordered the applicants' immediate release ${ }^{99}$; others denied that demand, referencing their continuous dangerousness to society ${ }^{100}$.

On $4^{\text {th }}$ May, 2011, the Federal Constitutional Court had to make a decision in connected procedures regarding the legality of the subsequent prolongation or the subsequent order of preventive detention and therefore the chance to create certainty of justice.

Owing to the ECtHR's judgments in terms of preventive detention, the res iudicata effect of the judgment in 2004 did not present an obstacle to a new judgment. ${ }^{101}$ Although the petitions were literally directed against the orders of continuance of preventive detention, the Federal Constitutional Court interpreted the petitions as being directed immediately against the legislative provisions that the lower courts' decisions were based on. ${ }^{102}$

The Federal Constitutional Court's judgment contains three focal points: Firstly, the Court declares that the current provisions regarding preventive detention do not comply with the requirements the Basic Law due to the effects of the ECtHR's rulings in German law (III.1.). Furthermore it draws up a list of requirements that future provision would have to comply with (III.2.). Finally, the Court lays down a

\footnotetext{
${ }^{95}$ BVerfG NJW 2011, p. 1931 et seq.

${ }^{96}$ For more details see Kinzig, NJW 2011, p. 177 et seq.

97 “Therapieunterbringungsgesetz” (ThUG) of $22^{\text {nd }}$ October, 2010, BGBl. I p. 2300, 2305.

${ }^{98}$ Bundesgerichtshof (BGH).

${ }^{99}$ BGH (4 ${ }^{\text {th }}$ Senate) NStZ 2010, p. 567; OLG Frankfurt am Main NStZ 2010, p. 573; OLG Karlsruhe NStZ-RR 2010 , p. 322.

${ }_{100}$ BGH (5 $5^{\text {th }}$ Senate) NJW 2011, p. 240; affirmative Windoffer, Die öffentliche Verwaltung (DÖV) 2011, p. 590 (596); OLG Celle NStZ-RR 2010, p. 322; OLG Stuttgart Recht und Politik (RuP) 2010, p. 15.

${ }_{101}$ BVerfG NJW 2011, p. 1931 (1934 et seq.), for more details in respect of the breaking through a res iudicata see above II. 6. c) bb).

${ }^{102}$ BVerfG NJW 2011, p. 1931 (1934).
} 
test for the treatment of people who are currently held in preventive detention based on those unconstitutional provisions (III.3.).

\section{The constitutionality of the current provisions}

According to the judgment, all of the provisions regarding the order and duration of preventive detention are unconstitutional. ${ }^{103}$ However, the Court's decision is not based on the prohibition of retroactive punishment in Article $103 \S 2$ Basic Law. As with the decision in 2004, the Court puts emphasis on the national concept of punishment being based on the principle of guilt and therefore preventive detention does not fit this concept of punishment - for the very reason that its purpose is not to expiate guilt but to prevent crimes. ${ }^{104}$

Instead, the Court bases the unconstitutionality of the provisions on two pillars: On the one hand, they are incompatible with the detainee's fundamental right of freedom (Article $2 \S 2$ and Article $104 \S 1$ of the Basic Law) because they do not fulfil the constitutional requirement of separation (Abstandsgebot). On the other hand, the provisions regarding the subsequent prolongation or the subsequent order of preventive detention respectively violate the requirement of the protection of the detainee's trust in his release (Vertrauensschutzgebot) (Article $2 \S 2$ and Article $20 \S 3$ of the Basic Law). Both of the pillars consider the ECtHR's evaluation of Articles 5 and 7 ECHR extensively.

\section{a) Violation of the requirement of separation (Abstandsgebot) based on Article $2 \S 2$ and Article $104 \S 1$ of the Basic Law}

According to the judges, the freedom of the individual is of great importance under the fundamental rights. Therefore, the current provisions ${ }^{105}$ are incompatible with Articles $2 \S 2,104 \S 1$ GG because they are not proportional. Since preventive detention interferes gravely with this right it can only be justified by a strict standard of proportionality which places severe demands on the underlying judgment and the arrangement of the enforcement of preventive detention. ${ }^{106}$ Preventive detention may only be decreed for the purpose of securing important objects of legal protection, whereby the public's need for security is sufficiently met. Both values have to be weighed up against each other in every single case.

With reference to its 2004 decision and the requirements of Article $7 \S 1$ ECHR, the Federal Constitutional Courts makes clear that preventive detention has to differ from imprisonment in a qualitative respect, it must not just be a prolonged imprisonment. ${ }^{107}$ It should not be based on the criminal's guilt but on his dangerousness for the public. Consequently, preventive detention might only be proportional if - apart from the privation of "external" freedom - further burden is

\footnotetext{
${ }^{103}$ BVerfG NJW 2011, p. 1931 (1934).

${ }^{104}$ BVerfG NJW 2011, p. 1931 (1942).

${ }^{105}$ Basically Articles $66 \mathrm{~b} \S 2$ and $67 \mathrm{~d} \S 3$ of the Criminal Code and Article 7 of the Juvenile Court Act.

${ }^{106}$ BVerfG NJW 2011, p. 1931 (1936).

${ }^{107}$ Leipold, NJW-Spezial 2011, p. 312.
} 
avoided. This means that, contrary to usual imprisonment, preventive detention must facilitate therapy and freedom. Moreover, it has to cease immediately when the general public's interests are no longer predominant to the detainees' right of freedom. ${ }^{108}$ The current system of detention does not fulfil these requirements at all, neither in a legal nor actual respect. ${ }^{109}$

\section{aa) Legal deficits of the current preventive detention system}

The Court finds fault in the legal provisions. Since the main laws of prison administration are applicable to preventive detention, the requirement of separation (Abstandsgebot) cannot be met. In particular, this is due to the current rules' lack of special possibilities in order to work towards the avoidance of later preventive detention while imprisonment is already being enforced. Apart from this, they do not comply with the requirement of support. Finally, the maximum time limit of two years for the control of whether preventive detention is still necessary is too long. 110

\section{bb) Actual deficits of the current preventive detention system}

Since the legal basis already fails to comply with the constitutional requirements, the enforcement of preventive detention does not, in practice, either. The objective of enforcement has to be the reduction of the detainee's dangerousness to the public and, in the long-term, the regaining of his freedom. The pursuit of these objectives has clearly failed in the past. For instance, there was not enough work done towards the regaining of freedom due to the lack of material and personal resources in the detention centres. This was even less so while these persons stayed in regular imprisonment. Furthermore, there were hardly ever any relaxations of the regime or any help during the time after release. ${ }^{111}$

The Court identifies that since 1998, the legislative branch kept on making preventive detention more severe without developing a general concept directed towards therapy and freedom which would comply with the requirement of separation (Abstandsgebot). Consequently, the current provisions violate Articles $2 \S 2$ and $104 \S 1$ of the Basic Law. ${ }^{112}$

\section{b) Violation of the detainee's trust in his release (Vertrauensschutzgebot) based on Articles $2 \S 2$ and $20 \S 3$ of the Basic Law}

The provisions regarding the subsequent prolongation or the subsequent order of preventive detention respectively violate the detainee's trust in his release protected by Article $2 \S 2$ and Article $20 \S 3$ of the Basic Law. ${ }^{113}$ One the one hand, because

\footnotetext{
${ }^{108}$ BVerfG NJW 2011, p. 1931 (1937).

${ }^{109}$ Hereafter, we may only point out the key statements of the Federal Constitutional Court's judgment. Otherwise we would go beyond the scope of this journal.

${ }^{110}$ BVerfG NJW 2011, p. 1931 (1939 et seq.).

111 BVerfG NJW 2011, p. 1931 (1940 et seq.).

112 BVerfG NJW 2011, p. 1931 (1939 et seq.).
} 
the requirements of distance (Abstandsgebot) is not met, and on the other hand, because the protection of trust in Article $20 \S 3$ is strengthened by Article 7 of the ECHR in such way that it guarantees almost absolute protection. ${ }^{114}$ There is no possible interpretation that is in conformity with the Constitution either. ${ }^{115}$

\section{Requirements for the future arrangement of preventive detention}

The legislator retains some room for manoeuvre for the future arrangements concerning preventive detention, albeit the Federal Constitutional Court establishes certain requirements which take into consideration the content of Article 7 $\mathrm{ECHR}^{116}$ :

\section{a) The ultima-ratio-principle}

Preventive detention may only be ordered if there is no less severe way to protect the public's need for security. In particular, while prison sentences are enforced, therapeutic measures have to be taken in order to reduce the prisoner's dangerousness so that preventive detention might in the best case be avoided afterwards.

\section{b) Requirement of individualisation and intensification}

The individual factors of the prisoner's dangerousness have to be analyzed. Based on this, a plan of proceeding in their case has to be established with the objective of reducing their dangerousness and providing them with a realistic prospect of freedom. This plan has to be updated constantly and has to be enforced with intense and individual care.

\section{c) Requirement of motivation}

In order to prevent disadvantageous effects of preventive detention on the detainee and to enable him to cooperate, he has to be motivated. The Court suggests a system of incentives that rewards cooperation with privileges or deprives them respectively.

\section{d) Requirement of separation}

The circumstances of preventive detention have to differ substantially from the enforcement of a prison sentence. Above all, life in preventive detention has to be adapted to life in freedom as far as security issues allow. Considering synergies in respect of infrastructure and security management, there is no full spatial separation of preventive detention from prison enforcement necessary, but rather a substantial one.

\footnotetext{
113 BVerfG NJW 2011, p. 1931 (1941, 1944).

${ }^{114}$ BVerfG NJW 2011, p. 1931 (1942).

115 BVerfG NJW 2011, p. 1931 (1944, 1945).

${ }^{116}$ BVerfG NJW 2011, p. 1931 (1938 et seq.).
} 


\section{e) Requirement of diminution}

The preparation of preventive detention's cessation requires the gradual relaxation of its enforcement in order to test the future release, e. g. in the form of day-releases or vacations etc. These must not be refused simply because of abstract dangers but only due to urgent reasons. In particular, day-release under supervision has to be granted. Finally, the affected person has to be systematically helped after their release, e. g. by assisted living or other forms of support. There has to be what the Court calls a suitable social room of reception created (geeigneter sozialer Empfangsraum $)^{117}$.

\section{f) Requirement of legal protection and support}

The legislator has to provide the detainee with effective legal rights directed to the enforcement of the aforesaid measures. Moreover, he has the right to counsel to protect his rights and interests.

\section{g) Requirement of control}

In procedural respects, the Federal Constitutional Courts demand that preventive detention's continuance has to be reviewed at least every year. If certain circumstances indicate that detention may no longer be necessary, an extraordinary examination has to take place. The longer preventive detention lasts, the more judicial control has to be intensified by reduction of the time periods and rising requirements to the order of prolongation.

\section{Procedure for the old cases affected by the ECtHR's rulings}

Both the persons affected by the subsequent prolongation or the subsequent order of preventive detention are violated in their rights of freedom and their protected trust. $^{118}$ In spite of the provisions' lack of constitutionality, the Federal Constitutional Court wanted to avoid a "legal vacuum" and therefore did not determine their invalidity but declared them as still applicable until new regulation has been introduced by $31^{\text {st }}$ May, 2013, at the latest. ${ }^{119}$

However, the infringement of these peoples' rights might only be justified by a strict standard of proportionality and in order to protect the highest standards of constitutional protection. Therefore, the interference in the detainee's trust in his release has to be weighed up against the public's need for security; however, the ECtHR's rulings have to be taken into consideration. The Court therefore concludes that the subsequent prolongation or the subsequent order of preventive detention may at present only be admissible under the following conditions: ${ }^{120}$

\footnotetext{
${ }^{117}$ BVerfG NJW 2011, p. 1931 (1939).

${ }_{118}$ BVerfG NJW 2011, p. 1931 (1941).

${ }^{119}$ BVerfG NJW 2011, p. 1931 (1945); see Article 35 of the Rules of Procedure of the Federal Constitutional Court (Bundesverfassungsgerichtsgesetz - BVerfGG).

${ }^{120}$ BVerfG NJW 2011, p. 1931 (1945) and number III of the operative provisions of the judgment.
} 
(1) There is an extreme threat of the most serious acts of violence or sexual crimes which derive from concrete personal circumstances or his behaviour and

(2) the person suffers from a psychic disorder.

The latter serves to fulfil the prerequisites of Article $5 \S 1 \mathrm{ECHR}$ in which only the alternative (e) comes into consideration.

It is remarkable that the Federal Constitutional Court ordered the courts responsible for prison enforcement to examine, without delay, whether these prerequisites were fulfilled in every (parallel) case. If not, detainees would have had to have been released by the $31^{\text {st }}$ December, 2011, at the latest. ${ }^{121}$ The cases of the complainants were referred to those courts which would have to examine the cases within six months in cases of young persons and twelve months in cases of adults. They would have to decide whether preventive detention should continue or not. ${ }^{122}$

\section{Critical review}

With its strict standard of proportionality, considering Article 5 and Article 7 of the ECHR, the Federal Constitutional Court tries to balance the public's need for security and the requirements the ECtHR has established.

\section{The Court's methodical approach}

This decision is methodically successful ${ }^{123}$, since it considers the ECtHR's rulings within the context of proportional interference in the rights guaranteed by Articles $2 \S 2,104 \S 2$ and Articles $2 \S 2,20 \S 3$ of the Basic Law, respectively. This way, the rulings are flexibly integrated but not transposed schematically. ${ }^{124}$ The Federal Constitutional Court keeps some room for manoeuvre so that it might, one the one hand, enforce the ECtHR's rulings and, on the other hand, it does not have to adapt the ECtHR's concept of punishment but may retain its own in Article $103 \S 2$ of the Basic Law (see above). ${ }^{125}$ Consequently, the Court upholds its line of the "Görgülü" case. ${ }^{126}$ Of course, the essential difference between Article $20 \S 3$ and Article $103 \S 2$ of the Basic Law lies in the absolute character of the latter which means that it is not open to a weighing up, as such. ${ }^{127}$ In contrast, interventions in Article $20 \S 3$ might be justified by conflicting constitutional law. ${ }^{128}$ Yet Article 7 $\S 1 \mathrm{ECHR}$ is also of an absolute nature meaning that the ECtHR's lack of weighing up with other objects of protection was just a consequence of its point of view. ${ }^{129}$

\footnotetext{
${ }^{121}$ According to number III 2. b) of the judgment's operative provisions the cases concerned are those of Article $67 \mathrm{~d} \S 3,66 \mathrm{~b} \S 2$ of the Criminal Code and Article $7 \S 2$ of the Juvenile Court Act.

${ }^{122}$ BVerfG NJW 2011, p. 1931 (1933 et seq.).

${ }^{123}$ Peglau, NJW 2011, p. 1924 (1927).

124 Cf. BVerfGE 111, p. 307 (323 et seq.).

125 BVerfG NJW 2011, p. 1931 (1942).

${ }^{126}$ BVerfGE 111, p. 307 (315 et seq.).

${ }_{127}$ Pieroth/Schlink, Staatsrecht II, 27 th ed. 2008, margin no. 1201.

${ }^{128}$ Jarass/Pieroth, Grundgesetz für die Bundesrepublik Deutschland, $11^{\text {th }}$ ed. 2011, Article 20, margin no. 72.

${ }^{129}$ Critically Windoffer, DÖV 2011, p. 590 (594 and 596).
} 


\section{The Court's conclusion}

It has to be remarked positively that the persistent violation of the requirement of distance (Abstandsgebot) finally results in constitutional consequences and that the law of preventive detention has to be overworked substantially. However, the Courts' conclusions in respect of the people affected by retroactivity fail, ${ }^{130}$ because the result is decisive for integration of ECHR law into the national law. The means that providing a remedy for the violation of the ECHR is left to the member states. What counts is only the result. ${ }^{131}$ In case of Article $5 \S 1$ ECHR - the right of freedom and security - the violation logically lies in the continuous detention. That violation of the Convention might only be remedied by the detainee's release which would be the concrete obligation to remedy (see Article 1 ECHR). ${ }^{132}$

Since the Federal Constitutional Court examines the legal justifications of Article $5 \S 1 \mathrm{ECHR}$ in detail, ${ }^{133}$ it seems to have shared these doubts. It is right that Article $5 \S 1$ (a) is not applicable to those cases. ${ }^{134}$ Furthermore, since there is no regular offence in planning, Article $5 \S 1$ (c) may be excluded. However, the Federal Constitutional Court's conclusion that privation of freedom might be justified by Article $5 \S 1$ (e) is problematic because at least two prerequisites are currently unfulfilled.

Procedurally, the order of confinement has to be issued in the frame of a special procedure which has to be geared to the needs of such people. ${ }^{135}$ This requirement should be fulfilled by the Therapy Confinement Act (ThUG). ${ }^{136}$ The competent courts are the Civil Chambers of the Regional Court (Landgericht) (Article $4 \S 1$ ThUG).

Regarding the substantive law, a detention due to an unsound mind would be possible under the following conditions according to the "Winterwerp-criteria",137. The unsound mind as a central requirement of Article $5 \S 1$ (e) ECHR has to be proved reliably which means that it requires a medical certificate diagnosing the mental illness. ${ }^{138}$

Furthermore, the forced confinement has to be necessary which means that no less severe, but equally effective means must be apparent. ${ }^{139}$ Confinement must only continue as long as the mental illness requires it. ${ }^{140}$

\footnotetext{
${ }^{130}$ Of a different opinion Windoffer, DÖV 2011, p. 590 (596 et seq.).

${ }^{131}$ Established law practice, e.g. ECtHR, Görgülü v. Germany, Application no. 74969/ 01, Judgment $26^{\text {th }}$ February, 2004, margin no. 46.

132 Pösl, ZJS 2011, p. 132 (145); Grabenwarter, JZ 2010, p. 857 (861).

133 BVerfG NJW 2011, p. 1931 (1943 et seq.).

${ }^{134}$ BVerfG NJW 2011, p. 1931 (1943 et seq.); in this respect the Federal Constitutional Courts is in accordance with ECtHR, M.v. Germany (fn. 6), margin no. 97 et seq.

${ }^{135}$ Meyer-Goßner, Strafprozessordnung, 54 th ed. 2011, Art. 5 EMRK, margin no. 6.

${ }^{136}$ See Kinzig, NJW 2011, p. 177 (181 et seq.) for the essential provisions and doubts.

${ }^{137}$ ECtHR, Winterwerp v. The Netherlands (fn. 56), margin no. 37 et seq.

${ }^{138}$ Cf. ECtHR, Herz v. Germany, Application no. 44672/98, Judgment 12th June, 2003, margin no. 47.

${ }^{139}$ Cf. ECtHR, Varbanov v. Bulgaria, Application no. 31365/96, Judgment $5^{\text {th }}$ October, 2000, margin no. 45 et seq.

${ }^{140}$ ECtHR, Winterwerp v. The Netherlands (fn. 56), margin no. 37, 39.
} 


\section{a) Unsound mind as the central requirement}

The ECtHR has not yet been given a definite interpretation of the term "unsound mind" in Article $5 \S 1$ (e) ECHR. Some scope of attestation belongs to the member states. ${ }^{141}$ A mere behaviour deviating from the norms prevailing in society does not yet mean an "unsound mind". ${ }^{142}$ Anti-social personality disorder or a psychopathic might fall under it but they do not need to necessarily do so. ${ }^{143}$ In its decision "Kallweit", the ECtHR refers to the German practice and consequently subsumes only personality disorders that disturb the perpetrator's capacity of control of his actions in the sense of Article 21 of the German Criminal Code, which lead to confinement in a psychiatric hospital in accordance with Article 63 of the German Criminal Code. ${ }^{144}$ Underlying this criterion, a confinement in accordance with ThUG might only be considered in exceptional cases. The interpretation which the legislator and the Federal Constitutional Court have in mind would therefore probably be estimated as an attempt to circumvent its rulings by the ECtHR ${ }^{145}$ - even more so since the ThUG was even created to handle the cases of persons affected by retroactive punishment. However, since the member states have a scope of attestation in respect of the term "unsound mind"146, it might be possible to subsume such cases as those involving some kind of a personality disorder will regularly arise - but only under the condition that German practice in court rulings change in the future.

\section{b) Necessity of confinement in a hospital or another appropriate insti- tution}

In order to comply with the requirements of legality and proportionality, the persons affected have to be placed in a hospital or at least in a similar institution ${ }^{147}$ a short term confinement in a prison is admissible until a place in an adequate institution is found.

Since none of the affected persons have been placed in a hospital or another appropriate institution, this requirement is not currently fulfilled. As long as they are confined in a regular prison, the detention may not be justified by Article $5 \S 1$ (e) ECHR so that the infringement of the Convention has not yet been remedied. Moreover, since actual enforcement of preventive detention has not changed yet, it must still be considered a punishment in the sense of Article $7 \S 1$ ECHR.

\footnotetext{
${ }^{141}$ Last ECtHR, Stojanovski v. the Former Yugoslav Republic of Macedonia, Application no. 41916/04, Judgment $22^{\text {nd }}$ October, 2009, margin no. 34 with further references.

${ }^{142}$ ECtHR, Winterwerp v. The Netherlands (fn. 56), margin no. 37

${ }^{143}$ ECtHR, Hutchison Reid v. United Kingdom, Application no. 50272/99, Judgment 20 ${ }^{\text {th }}$ February, 2003, margin no. 19.

${ }^{144}$ ECtHR, Kallweit. v. Germany (fn. 7), margin no. 55.

145 Affirmative Renzikowski, ZIS 2011, p. 531 (538); Of a different opinion Peglau, NJW 2011, p. 1924 (1925).

${ }^{146}$ Last ECtHR, Stojanovski v. the Former Yugoslav Republic of Macedonia (fn. 141), margin no. 34 with further references.

${ }^{147}$ ECtHR, Hutchison Reid v. United Kingdom (fn. 143), margin no. 48.
} 
Thus, the ongoing detention of the persons affected by retroactivity is still infringing the European Convention on Human Rights. Since the Federal Constitutional Courts set a time limit until 31 ${ }^{\text {st }}$ May, 2013, for a new regulation, the infringement will continue for a rather long time.

\section{c) Weakening of the ECtHR's authority}

The continuing infringement of the Convention approved by the Federal Constitutional Court also sets a doubtful example. The ECtHR lacks jurisdictional authority to enforce its rulings. The effectiveness of International Law, and particularly of the ECHR, is based on the states' commitment to the existence of longterm common and mutual interests; in the case of the ECHR, the principle of pacta sunt servanda has to be added. ${ }^{148}$ This system is weakened if Germany, as an ECHR member state does not comply with it, on the one hand, and urges states like Russia or Turkey, who are responsible for the majority of violations, to stop their infringements of the Convention, on the other hand. ${ }^{149}$

As experienced in the "Kallweit" decision, the ECtHR appealed to the German courts and authorities to stop the continuous violation of the Convention and to meet their responsibility for application and enforcement of the complainants' right of freedom. ${ }^{150}$ Unfortunately, this appeal fell on deaf ears with the Federal Constitutional Court - despite the right of freedom being one of the core guarantees of the ECHR.

\footnotetext{
148 Geiger, Grundgesetz und Völkerrecht mit Europarecht, $5^{\text {th }}$ ed. 2010, p. 9.

149 Pösl, ZJS 2011, p. 132 (146); similarly Gaede, Online-Zeitschrift für höchstrichterliche Rechtsprechung im Strafrecht (HRRS) 2010, p. 329 (337).

${ }^{150}$ ECtHR, Kallweit. v. Germany (fn. 7), margin no. 83.
} 